\title{
Parenting and Responsibility: Holding Parents Accountable for Children's Antisocial Practices
}

\author{
E.A.Uwe, P.N.Asuquo and E. E. Ekuri \\ Department of Educational Foundations, University of Calabar, Calabar, Nigeria \\ E-mail: ekauwe2002@yahoo.com
}

KEYWORDS Parents. Parenting and Responsibility. Anti-Social Practices

\begin{abstract}
Proper nurturing of children is the primary responsibility of parents. Parents have inescapable responsibilities when bringing up their children. These responsibilities are automatically conferred on both parents of the child right from the child's birth. They are expected to guide and modify the behaviour of their child to conform with the acceptable behaviours in the society as well as participate in activities aimed at preventing crime or disorder being committed by their children. Ironically, some parents have failed in these roles and functions. They adopt too much permissive and laissez-faire parenting styles that inadvertently make their children vulnerable to anti-social behaviours. This paper focuses on parents as the catalysts for children's behaviour. The rationale for children's anti-social behaviours are highlighted as well as some of the corrupt behaviours parents exhibit. The root causes of these behaviours are brought to the limelight and suggestions proffered for improving the task of parenting.
\end{abstract}

\section{INTRODUCTION}

Youths are our expected future leaders. In a society where these would be future leaders are engaged in crimes, violence, and other delinquent and corrupt behaviours, there can never be peace, progress and sustainable development. Peace is an important phenomenon, a condition the nation, the world and every individual need. In the absence of peace there is the possibility of instability, insecurity, burglary, thugery, assault, rape, street ganging, drug peddling and abuse, and other vices.

In our contemporary Nigerian setting, the authors observed that a lot of people exhibit dishonest behaviours without any fear of apprehension. Some of these behaviours include taking part in bank fraud, taking loans from banks without adequate collateral, demanding bribe before appointment is offered to prospective applicants, money laundering, involvement in massif scale theft popularly known as ' 419 ' or Advanced Fee Fraud and getting bribe and setting culprits free from prison custody.

In the urban areas, the streets and residences are no longer save, no matter how well fortified they may be. Streets-smart-boys, popularly known as "Area-boys" are found everywhere roaming the streets, harassing and extorting money from innocent people. The youths are involved in cultism, armed robbery, examination malpractices, assaults, rape, violence, substance abuse, alcoholism, certificate racketing and vandalism, to mention but a few. Sadly enough, children manifest some of these antisocial behaviours before they even start school.

These corrupt practices have dominated the social landscape of the nation for decades. They have been so prevalent in both low and high places that it has necessitated the establishment of some structures by the Federal Government, such as, the Tribunal for Corrupt Practices (TCP), Code of Conduct Bureau (CCB). Nigerian Drug Law Enforcement Agency (NDLEA), Anti-Trade Malpractice Commission (AMC), Economic and Financial Crimes Commission (EFCC), Independent Corrupt Practice Commission (ICPC) and others to check such negative behaviours.

This prevailing atmosphere has given rise to some pondering questions as to what could have been the possible root causes of children, youths and even adults involvement in antisocial behaviours. Could parents, who are expected to be the custodians of appropriate behaviour in children be held accountable for such behaviours as a result of their laxity and failure in carrying out their parental responsibilities. Do they in one way or the other contribute to their children's involvement in anti-social practices.

Parenting in the Nigerian context entails the nurturing relationship between the parents (or parent in the case of single parents) and the child. In this relationship the parents have the responsibility and obligation to meet the needs 
of the child, as well as teach the child ethical and spiritual principles of the society. The parents are expected to pass on the societal values, such as, respect for others, self-control, goodness, altruism, truth, fairness and honesty.

The family in which parents are the leaders is a great socialization agent. It is the first social setting that a child experiences in life. Within this social setting, the child begins his socialization process. The family is therefore involved in molding the individual behaviour from the formative stage. Once the family fails in its obligations, the entire society stands to suffer the consequences.

Unfortunately, some parents who are at the head of this socialization unit expose their children to antisocial behaviours. Some of them use their children in planting and/or peddling Indian hemp and other dangerous substances. Some purchase fake certificates for their children to gain admission into higher institutions of learning and some even pay huge sums of money to their children's teachers/lecturers to alter their failed grades, etc.

\section{RATIONALE FOR CHILDREN'S ANTI-SOCIAL BEHAVIOUR}

Our children represent the future generation, and so, they must be properly molded for their future roles. The child's parents have the greatest part to play in this molding process as they are the first socializing agents to the child. Therefore, the type of training the parents give the child and the values they propagate will determine the future life style of the child. This is because once an attitude has been established concerning a certain behaviour, it becomes difficult to eradicate (Pierson and Thomas, 2002).

In Skinner's (1953) instrumental theory, also known as 'operant conditioning', he demonstrated that the environment has a much greater influence on learning and behaviour. This is mostly observed at the formative period of one's life. Environmental response to behaviour according to Skinner serves either to reinforce or eliminate learning and behaviour. According to Skinner, if a response is reinforced, it is more likely for that behaviour to re-occur. Therefore parents who reinforce antisocial behaviours in their children encourage such behaviour to reoccur. So, it is the responsibility of parents to always respond appropriately to their children's behaviour so that the obnoxious ones are eliminated, while the accepted ones are strengthened.

Nagin and Farrington (1992) also believe that the tendency to commit crime is established early in life, perhaps around the pre-school years, and this is the period that the home environment determines almost all that the child does or leaves undone for example, his actions and inactions. According to them once a child manifests an unwanted behaviour, he is likely to behave that way again when such conditions occur. This position is in line with Wilson and Herrnstein's (1985) theoretical assertion that there exists a positive association between past and future criminal behaviour. To them, the best predictor of crime is past criminal behaviour.

Sutherland (1973), in his theory of differential association, arrived at some principles related to delinquent behaviours. The first principle is that delinquent behaviour is learned. He argued that only sociological explanation could account for a person's involvement in delinquency. The second principle is that delinquent behaviour is learned, while communicating with others in intimate groups. Sutherland and Cressey (1978) in their investigation focused on the family or peer group as the most likely source of initiation into delinquent value and activities. The third principle according to Sutherland (1973) claims that learning process includes two different elements, techniques (how to commit offences) and attitudes or rationalization (how to justify the offences against self and others). The fourth principle states that rationalization and attitudes toward the law are learned from people whom we associate with and who hold attitudes that favour either obeying the laws or violating them. The fifth principle states that people who are more exposed to verbal signs and suggestions will break the law more than those who are obedient. Thus, parents who give the hint that it is acceptable to fight, cheat or lie may foster delinquent children. However, the sixth principle espoused by Sutherland is that the longer and earlier youths are exposed to a set of attitudes about delinquency, the more influenced they will be.

Bandura (1971) in his social learning theory stressed the potent influence of modelling on behaviour. He argued that behaviour is the joint product of the person and the environment. He acknowledges that people can alter their environment, which therefore turn round to alter their behaviour. In his view of behaviour change 
processes, Bandura places great prominence on observational learning and modelling. According to Bandura, practically all of the learning that people can acquire through their own direct experience could be acquired vicariously. This implies that such behaviour is acquired at second hand by observing someone else. Four processes influence observation of learning process in Bandura's view, namely: attention, retention, performance and motivation. People attend to the behaviour of a model and retain the modelled information, which is aided by imagery and verbal coding and then perform the act so modelled by putting the appropriate motor movement from the information gained. Motivation therefore, determines whether or not the person will deploy the behaviour so modelled.

Aggression is to a great extent a learned behavour (Bandura, 1973; Berkowitz, 1962; Eron, Walder and Leftkowitz, 1971). Morton (1987) argued that socio-culturally, delinquent children are frequently reared in homes that offer little understanding, affection, stability or moral clarity. Lotz (1979) in his study also found that person turn to crime because they were not given enough discipline when young. Monteleone (1996), Ekpo (1996) and Uwe and Obot (2000) in their view, argued that when parents fail to teach their children the necessary social skills for successful interaction in the world, such parents automatically leave the children vulnerable to learn inappropriate behaviours from those who would take advantage of them. The further assert that parents who themselves display antisocial behaviours commonly transmit such values, action and attitudes to their children.

Commenting on the cost of pathological gambling to families and friends, Awake (2002) reported that problems of gambling spread from parents to child, in that, children of compulsive gambling parents are likely to engage in delinquent behaviours, such as, smoking, drinking and using drugs. The children also have an increased risk of developing problems of pathological gambling themselves. Awake (2002) further reported a survey result in the United Kingdom, which found that, among adolescents who gamble, 46 percent stole from their family to support their habit.

Monteleon (1996) argued that corrupting could begin with rewarding the infants; encouraging violence towards peers; laughing at anti-social behaviours; and encouraging children to sell, deliver and use drugs. Single parenthood also play a part in the degenerative function of the family. Swadener (1990), Lubeck and Garrett (1990) and Ekpo (1996) opined that adolescents who terrorize people particularly in urban areas, do so because their single-parents households have failed in adequately teaching them the value of human life and decency.

Some parents are hostile, indifferent and rarely show affection to their children Uwe (1997). They neglect or beat their children, but rarely exercise consistent firm guidance. Some are so permissive that they do not care about what happens to their children, or what they do. Such parents according to Bandura and Walter (1959), and Glueck and Glueck (1960) produce delinquent children. Furthermore, in permissive homes, children get premature autonomy. They come and go as they wish. With such inconsistent parents, children become relatively confused as to the reactions they would get. As an example, coming home late one day, may result in scolding or beating, and coming late next day may be overlooked. Patterson (1980) affirmed that not only do parents of chronic delinquents not know how to parent effectively, but also many of them do not care. Wahua (2001) opined that some parents even rise to the children's defence and accuse others for picking on their children even when it is obvious that the children have committed the crime of which they are accused.

Some parents do not display proper role model for their children to emulate (Uwe 1997). They openly display anti-social behaviours before their children, for example offering and accepting bribes. Some parents who experienced abusive parenting from their parents continue to perpetuate these negative attitude thereby making their children become toughened and so the cycle goes on. In Ekanem's (2000) view, there are also parents who do not have time to talk with their children nor listen to them. Such children are left on their own and have no feelings of being wanted. They do not develop good sense of self-worth and positive self-concept. As a result of this neglect, the children judge themselves as misfits with unbalanced personality.

Ekanem (2000) argued that parents who do not establish a clear consistent boundaries and limits for their children could be so permissive that children are left unguided as to what the acceptable behaviour should be. Such children accor- 
ding to her often put themselves into unwarranted problems even with law enforcement agents.

\section{PARENTS AS PERPETUATORS OF CORRUPT BEHAVIOURS}

Children's welfare and rights have been a central concern of the United Nations since its inception in 1945. The United Nations Convention On the Rights of the Child (1991) acknowledges the primary role of the family and parents in the care and protection of children. According to the Convention, parents have the primary responsibility for the child's upbringing. Unfortunately, this primary function has degenerated and has not been achieved as expected. This degenerative symptom of the family has permeated the entire social fabric of the nation. Parents, instead of enhancing positive development in their children, knowingly or unknowingly encourage and reinforce children's anti-social behaviour.

Many sociologists, such as Sears et al. (1957), Patterson (1976), Whaler (1976), Atkeson and Forehand (1981), Monteleone (1996), assert that parent-child interaction is central in shaping and maintaining high level of either positive or negative behaviours. Monteleone (1996) argued that parents who ignore or reinforce delinquent behaviour are corrupt themselves. Patterson (1976) views a coercive family as breeding aggressive children. He opined that a coercive method of interpersonal control predominates in such families. According to him, this pattern of family interaction develops as a result of parental deficits in child management.

\section{PARENTS CONTRIBUTION TO CHILDREN'S ANTI-SOCIAL BEHAVIOURS}

Parents as leaders should be role models. Achebe (1998) asserts that people look up to their leaders as role models. They copy their actions, behaviour and even mannerisms. Achebe (1998: 37) stated therefore that "if a leader lacks discipline the effect is apt to spread automatically down to his followers". The implication is that, if parents as leaders to be emulated by their children exhibit negative behaviours, then the tendency will be that children, their followers will copy those behaviours.
Moneteleon (1996) asserts that some parents go to the extent of conveying approval of, or encourage their children's precocious interest in the areas of sexuality, aggression, violence and substance abuse. He enumerated some parental corrupt behaviours as follows:

- Allowing and/or forcing child to watch pornographic material,s

- Teaching child sexually exploitative behaviours,

- Teaching child illegal activity,

- Knowingly allowing others to teach illegal activity to the child,

- Praising child for antisocial/illegal activity,

- Assisting child in delinquent behaviour,

- Failing to discipline child for delinquent behaviour,

- Teaching child that "bad is good and good is bad",

- Giving drugs or other contraband to child,

- Exposing child to harmful influences or situations,

- Using child as a spy, ally or confident in parents romantic relationships, marital or divorce problem (p. 129).

Other corrupt behaviours in parents observed by researchers such as, Ekpo (1996), Isangedighi (1997), Okon (1997), Uwe (1997), Ekanem (2000), Eweniyi (2000), Obot (2000), Uwe et al. (2004) include:

- Sexual exploitation of children, for example encouraging prostitution by introducing teenage girls to "Sugar Daddies" for monetary gains;

- Master sleeping with his housemaid;

- Allowing children sleep on the same bed with adult family friends thereby encouraging assault and rape;

- Sending young children as forced or bonded servants in exchange of small loans or payment of debt thus encouraging child abuse;

- Involvement of children in planting and peddling Indian hemp and other substances;

- Involvement in human trafficking;

- Use of children in errands to purchase items such as cigarettes, drugs, alcohol including ogogoro (illicit gin);

- Encouraging the child to grow faster than his/her age, for example, perming a child's hair, using adult make-up on the child and allowing the child out with peers unknown to parents and without their permission;

- Failure to provide the necessary control, or 
role model for learning socialization and responsible behaviour;

- Ritualistic abuse of the child, for example, using a girl child as a maiden in the worship of water goddess;

- Involvement of children in gambling;

- Offering and accepting bribes even before the child;

- Purchasing fake certificate for child to gain admission into higher institution of learning;

- Paying lecturers and teachers to alter a child's failed scores;

- Misappropriation of public funds;

- Non-completion of contract transaction;

- Dishonesty in business dealings, for example, swearing falsely before the child to customers;

- Swindling in the name of religion;

- Encouraging school absence to enable the child go street hawking;

- Withdrawal of child prematurely from school for exploitative purposes;

- Verbal battering of the child;

- Impaired parenting; and

- Trafficking drug by hiding substances on an innocent infant's body.

\section{POSSIBLE CAUSES OF PARENTAL CORRUPT BEHAVIOURS}

The causes of parental corrupt behaviour are complex, multiple and interactive. Decay and Travers (1996) opined that constitutionally more males than females commit crimes and that younger males than older males are involved in criminal behaviour. The also argue that developmentally broken families are more prone to crime than intact families.

Poverty is a leading possible cause of parental antisocial behaviours. In our Nigerian setting, having many children receives social approval and honour (Afuekwe 1992). Many parents end up breeding many children without the necessary resources to cater for them. They often hope that God would provide for their needs. With the austere economic situation in the nation, the dearth of employment and inflation, such parents have too many mouths to feed, more so as their young adult children continue to depend on them for their needs because of unemployment. Forced by their circumstances, such parents indulge themselves in antisocial activities in order to sustain the family.

Another important cause of parental corrupt behaviour is greed. The society is moving very fast in fashion and wealth because of globalization and information technology. Everyone wants to be like the Joneses, driving expensive cars and living in luxurious apartments. There is an axiom which says that "money is the root of all evil". Everybody wants to have it either by crook or crude way. Money has become a surrogate god to many and greed is a debilitating social sickness. Greed and lust for money drive many parents into crimes.

Some parents find it hard to revolutionize the way they were brought up (Monteleone 1996). They repeat the parenting cycle and pass on the type of parenting they received. Some are so permissive and non-challant. They are less interested in bringing up the child in the acceptable way. Moreover, attitude of Nigerians towards corrupting behaviour is appalling. Corrupt behaviours are sometimes regarded as normal and anybody who succeeds and gets away, feels he/ she is intelligent afterall.

\section{RECOMMENDATIONS FOR IMPROVED PARENTING SKILLS}

There is the need to bring up children that are well-adjusted. To assist parents meet their responsibilities, the following strategies are recommended:

- Parents should display proper role model for children to emulate;

- They should show enough affection to their children.

- They should endeavour to stop perpetuating abusive parenting that they themselves went through.

- Parents should find time to talk with their children and also listen to them in order to get into their innermost feelings, thoughts and emotion and guide them properly.

- Children should be helped to develop the sense of self worth and positive self concept. This is because the way the child judges himself determines how balance his personality is.

- Clear consistent boundaries should be set for children. These help to guide children on the acceptable behaviour by parents.

- There should be regular monitory of what children do.

- Parents should create a secure environment where peace, love and harmony prevail. 
- Lastly, priority should be given to spirituality. Parents should meditate on the scriptures, pray and worship together with their children.

\section{CONCLUSION}

Parents have some responsibilities which they can never escape from in as much as they bring children into this world. They are responsible for meeting the physical, social, emotional, psychological and spiritual needs of their children. Through proper socialization, they are expected to nurture the children and groom them, ready for launching them into the society. Unfortunately, some of these parents fail in these responsibilities and rather encourage some antisocial behaviours in their children. They openly exhibit those maladaptive behaviours for children to emulate and do not monitor what their children do. There is therefore the need to arrest this prevailing conditions if the country is to forge ahead in its sustainable development programmes. As future leaders it is imperative to 'catch' the youths when they are young. When children are well-adjusted and disciplined, the nation, the citizenry and the world at large will experience peace.

\section{REFERENCES}

Achebe, C.: The Trouble with Nigeria. Fourth Dimension Publishing Company, Enugu (1998).

Afuekwi, C. I.: A philosophical inquiry into religious and Scoial life in Igbo land: Alor as a case study. Associated Publishers and Consultants, Calabar: (1992).

Atkeson, B. M. and Forehand R. (1981). Conduct disorders. In: Behaviour Assessment Of Childhood Disorders. E. J. and 1. O. Terdal (Eds.). Guilford, New York. (1981).

Awake: What is Wrong with Gambling. Watchtower Bible and Tract Society, New York July 22 (2002).

Bandura, A.: Psychotherapy based upon modelling principles. Pp. 653-708. In: Handbook of Psychotherapy and Behaviour Change. A. E. Bergin and S. L. Garfield (Eds.). Wiley, New York (1971).

Bandura, A. and Walters, R. H.: Adolescent Aggression. Ronald, New York (1959).

Berkowitz, L.: Aggression: A Social Psychological Analysis. McGraw-Hill, Boston (1962).

Decay, J. S. and Travers, J. F.: Human Development Across the Life Span. Boston: McGraw-Hill, Boston (1996).

Ekanem, T. F.: Parental care and child moral development. UJOWACS. University of Uyo Journal of Women Academics, 1(1): 157-163 (2000).

Ekpo, S.: Juvenile Delinquency in Nigeria. ABBNNY Educational Publishers, Uyo (1996).
Eron, L. O., Walder, 1. O. and Leftkowitz, M. M.: The Learning of Aggression in Children. Little, Brown, Boston (1971).

Eweniyi, G. B.:Child Sexual Abuse and the Rights of the Nigerian Child. The Counsellor. 18(1): 166-172 (2000).

Glueck, S. and Glueck, E.: Unraveling Juvenile delinquency. Commonwealth Fund, New York (1960).

Isangedighi, A. J.: Youths on the margins: Indices of indiscipline behaviour. Nigerian Journal of Educational Foundations, 1(1): 18-20 (1997).

Lotz, R.: Public anxiety about crime. Pacific sociological Review. 22: 241-254 (1979).

Lubeck, S. and Garrett, P.: The social construction of the "at risk" child. Journal of Sociology of Education, 11(3): 327-340 (1990).

Monteleone, J. A.: Recognition of child abuse for the mandated. Reporter, G. W. medical Publishing, St. Louis, Missiour (1996).

Morton, I.: Childhood aggression in the context of family Interactions. In: Childhood Aggression and Violence. D. Crowell, I. Evans, and C. Odonnell (Eds.). Plenum Press, New York New York: (1987).

Nagin, D. and Farrington, D.: The stability of criminal potential from childhood and adulthood. Criminology, 30: 235-260 (1992).

Obot, A. E.: Single Parenthood. In: Marriage Counselling: Issues and Solutions. E. A. Uwe and A. E. Obong (Eds.). Pyramid Publishers, Calabar (2000).

Okon, M. O.: Parental role in Behaviour Modification: Implication for Counselling. The Calabar Counsellor, 1(2): 138-145 (1997).

Patterson, G. R.: The aggressive child: Victim and architect of a cursive system. In: Behaviour Modification and family. L. G. Hamerlynck, L. C. Handy, and E. J. Masia (Eds.). Brunner/Mazel, New York (1976).

Patterson, G. R..: Children who steal. In: Understanding Crime. I. Hirschi, and M. Gottfredson (Eds.) Sage, Berverly Hills, Calif. (1980).

Pierson, J. and Thomas, M.: Collins Dictionary: Social Work. HarperCollins Publishers, Great Britain (2002).

Sears, R. R., Maccoby, E. E.; and Levin, H.: Patterns of Child Rearing. Harpey and Row, New York (1957).

Skinner, B. F.: Science and Human Behaviour. The Free Press, New York (1953).

Sutherland, E. H.: On Analyzing of Crime University of Chicago Press, Chicago (1973).

Sutherland, E. H., and Cressey, D. R.: Criminology. Lippihcott, Philadelphia (1978).

Swadener, E. B.: Children and families "at risk": Etiology, Critique and alternative paradigms. Educational Foundations, 4(4): 17-39 (1990).

United Nations: Convention on the Rights of the Child. United Nations, New York (1991).

Uwe, E. A.: Parental Roles in Behaviour modification of youths. The Calabar Counsellor 1(1): 121-126 (1997).

Uwe, E. A. and Obot, A. E.: Marriage Counselling: Issues and Solutions. Pyramid Publishers, Calabar (2000).

Uwe, E. A., Ekuri, E. E. e. and Asuquo, P. N.: African Women and Vulnerability to HIV/AIDS: Implications on Female related Cultural Practices. A 
Paper Presented at the Pan African Anthropological Association Conference, Legon, Ghana August $2^{\text {nd }}-6^{\text {th }}$ (2004).

Wahua, T. A. T.: Home Harmony: Dalitt Publishing Company (2001).

Whaler, R. O.: Deviant child behaviour within the family: Develomental speculations and behaviour change strategies. In: Handbood of Behaviour Modification. H. Leitengerg (Ed.). Prentice-Hall, Englewood Cliffs, N. J. (1976).

Wilson, J. and Herrnstein, R.: Crime and Human Nature. Simon and Schuster, New York (1985). 